\title{
TLR7 Activation of Macrophages by Imiquimod Inhibits HIV Infection through Modulation of Viral Entry Cellular Factors
}

\author{
Feng-Zhen Meng ${ }^{1,2}$, Jin-Biao Liu ${ }^{2}$, Xu Wang ${ }^{2}$, Peng Wang ${ }^{2}{ }^{(\mathbb{D}}$, Wen-Hui Hu ${ }^{2}$, Wei Hou ${ }^{1, *}$ and Wen-Zhe Ho ${ }^{2, *}$ \\ 1 School of Basic Medical Sciences, Wuhan University, Wuhan 430000, China; mengfz0128@126.com \\ 2 Department of Pathology and Laboratory Medicine, Temple University School of Medicine, \\ Philadelphia, PA 19140, USA; jinbiao.liu@temple.edu (J.-B.L.); xu.wang@temple.edu (X.W.); \\ peng.wang@temple.edu (P.W.); whu@temple.edu (W.-H.H.) \\ * Correspondence: houwei@whu.edu.cn (W.H.); wenzheho@temple.edu (W.-Z.H.)
}

check for

updates

Citation: Meng, F.-Z.; Liu, J.-B.; Wang, X.; Wang, P.; Hu, W.-H.; Hou, W.; Ho, W.-Z. TLR7 Activation of Macrophages by Imiquimod Inhibits HIV Infection through Modulation of Viral Entry Cellular Factors. Biology 2021, 10, 661. https://doi.org/ 10.3390/biology10070661

Academic Editors: Rongtuan Lin and Zhenlong Liu

Received: 8 June 2021

Accepted: 8 July 2021

Published: 13 July 2021

Publisher's Note: MDPI stays neutral with regard to jurisdictional claims in published maps and institutional affiliations.

Copyright: (c) 2021 by the authors. Licensee MDPI, Basel, Switzerland. This article is an open access article distributed under the terms and conditions of the Creative Commons Attribution (CC BY) license (https:/ / creativecommons.org/licenses/by/ $4.0 /)$.
Simple Summary: The Toll-like receptor (TLR) 7 is highly expressed by immune cells including macrophages. Agonists to TLR7 are attractive therapeutic agents as they have the potential of activating both innate and acquired immunity against viral infections. Imiquimod, a specific TLR7 agonist, has been successfully used for the topical treatment of genital/perianal warts in immunocompetent individuals. Here we examined the anti-HIV effect of imiquimod in primary human macrophages and demonstrated that TLR7 activation by imiquimod could effectively inhibit infection of the cells by different strains of HIV. Further mechanistic studies revealed that while imiquimod had little effect on interferons expression, its treatment of macrophages resulted in the increased production of the CC chemokines, the natural ligands of the HIV entry co-receptor CCR5, and decreased expression of CD4 and CCR5. These findings are clinically important and indicate that activating the intracellular antiviral immunity by imiquimod has the potential for developing TLR7 agonist-based therapy for HIV infection.

Abstract: The Toll-like receptor (TLR) 7 is a viral sensor for detecting single-stranded ribonucleic acid (ssRNA), the activation of which can induce intracellular innate immunity against viral infections. Imiquimod, a synthetic ligand for TLR7, has been successfully used for the topical treatment of genital/perianal warts in immunocompetent individuals. We studied the effect of imiquimod on the human immunodeficiency virus (HIV) infection of primary human macrophages and demonstrated that the treatment of cells with imiquimod effectively inhibited infection with multiple strains (Bal, YU2, and Jago) of HIV. This anti-HIV activity of imiquimod was the most potent when macrophages were treated prior to infection. Infection of macrophages with pseudotyped HIV NL4-3- $\Delta$ Env-eGFPBal showed that imiquimod could block the viral entry. Further mechanistic studies revealed that while imiquimod had little effect on the interferons (IFNs) expression, its treatment of macrophages resulted in the increased production of the CC chemokines (human macrophage inflammatory protein-1 alpha (MIP-1 $\alpha$ ), MIP-1 $\beta$, and upon activation regulated normal $\mathrm{T}$ cells expressed and secreted (RANTES)), the natural ligands of HIV entry co-receptor CCR5, and decreased the expression of CD4 and CCR5. The addition of the antibodies against the CC chemokines to macrophage cultures could block imiquimod-mediated HIV inhibition. These findings provide experimental evidence to support the notion that TLR7 participates in the intracellular immunity against HIV in macrophages, suggesting the further clinical evaluation of imiquimod for its additional benefit of treating genital/perianal warts in people infected with HIV.

Keywords: Toll-like receptor 7; CC chemokine; macrophages; human immunodeficiency virus; imiquimod

\section{Introduction}

Intracellular innate immunity is an essential component of host immune responses against virus infections including HIV [1]. Macrophages play an important role in the 
immunopathogenesis of HIV infection and the development of acquired immunodeficiency syndrome (AIDS). Macrophages, along with $\mathrm{CD} 4^{+} \mathrm{T}$ cells, are the major targets of HIV $[2,3]$. Because macrophages express both the primary receptor CD4 and co-receptor CCR5, they are highly susceptible to productive infection by CCR5-tropic HIV strains [4]. It is known that antiretroviral therapy (ART) effectively suppresses HIV in infected individuals. However, even long-term ART could not eradicate HIV in cellular reservoirs, including macrophages [5]. When compared to $\mathrm{CD}^{+} \mathrm{T}$ cells, HIV-infected macrophages are more resistant to apoptosis and less sensitive to ART. These pathological properties of macrophages make them an ideal reservoir for HIV persistence and latency as well as a therapeutic target $[2,6]$. In addition, because of their ability to infiltrate virtually all organs, HIV-infected macrophages contribute to the spread of the virus [3]. Therefore, it is important to target macrophages and identify cellular restriction factors that can suppress and eliminate HIV in these cells.

Innate immunity is composed of several families of pattern recognition receptors (PRRs) that recognize molecular structures of pathogens, known as pathogen-associated molecular patterns (PAMPs) [7]. TLRs are the first PRRs to be identified and the most well-characterized $[8,9]$. TLRs are largely classified into two subfamilies based on their localization: those on the cell surface and the intracellular endosomal TLRs. TLR7 is one of the intracellular TLRs which recognizes ssRNA. Through TLR7, the hosT cells detect the invasion of the ssRNA viruses, including HIV [10]. Importantly, the activation of TLR7 signaling pathways results in the release of antiviral and pro-inflammatory cytokines, such as type I interferons (IFN- $\alpha$ and IFN- $\beta$ ) which exert antiviral activities by inducing IFN-stimulated genes (ISGs). Studies have shown that the activation of TLR7/8-mediated signaling pathways upon treatment, with either ssRNA or the small molecule TLR7/8 agonist such as resiquimod (R-848), greatly reduced the ability of lymphoid tissue to support HIV infection [11-13]. The investigators concluded that the combined effects of multiple cytokine changes induced by resiquimod, rather than IFN- $\alpha$, were primarily responsible for the resiquimod-induced antiviral effect [11].

As a synthetic and selective ligand for TLR7, imiquimod can specifically stimulate TLR7 [14] and induce potent antiviral activities against some pathogenic human viruses including herpes simplex virus 2 [15], Sendai virus [16], human papillomavirus (HPV) [17], and influenza A virus [18]. Furthermore, Angelopoulou et al. [19] recently reported that imiquimod can be an ideal option for the management of SARS-CoV-2 infection. Clinically, imiquimod cream has been successfully used for the treatment of external genital and perianal warts in patients infected with both HPV and HIV [17,20-23] as it stimulates cell-mediated immune responses through the localized induction of IFN- $\alpha$ and other cytokines. Imiquimod is an immunomodulator of monocytes, macrophages, and dendritic cells which express TLR7 and produce IFNs as well as other antiviral cellular factors. However, studies have shown that the ability of these immune cells to produce type I IFNs and ISGs is impaired by HIV infection [24-28]. Liu et al. [29] recently demonstrated that the HIV infection of primary human macrophages and microglial cells suppressed the TLR3 activation-induced expression of the antiviral ISGs and the HIV-restriction miRNAs. While these findings suggest a mechanism for HIV persistence and latency in macrophages and microglial cells, they also indicate the importance and necessity to determine whether to immunologically activate intracellular innate immunity by imiquimod, a TLR7 agonist, to protect macrophages from HIV infection and suppress the viral replication.

\section{Materials and Methods}

\subsection{Cell Culture}

Freshly isolated human peripheral monocytes were obtained from the Human Immunology Core at the University of Pennsylvania. The culture conditions for the monocytes' differentiation into macrophages were described previously [30,31]. From day 5 to day 7 in culture, the majority $(>95 \%)$ of the monocytes became macrophages, which showed the characteristic morphology (spindle-shaped and large multinucleated cells) of primary hu- 
man macrophages while they remained positive for the CD14 marker. HEK-293 T cells were maintained in DMEM (Gibco, New York, NY, USA) with 1\% MEM NEAA (Gibco, New York, NY, USA), 1\% penicillin-streptomycin (Lonza, Walkersville, GA, USA), 0.5\% L-Glutamine (Gibco, New York, NY, USA), and 10\% fetal bovine serum (Corning, New York, NY, USA).

\subsection{Virus and Reagents}

Based on the differential usage of co-receptors (CCR5 and CXCR4), HIV isolates have been referred to as R5-, X4-, or dual-tropic strains [32]. The HIV R5-tropic strains (Bal, Jago, and YU2) were obtained from the AIDS Research and Reference Reagent Program of the National Institute of Health (NIH, Bethesda, Rockville, MD, USA). Imiquimod, a synthetic TLR7 ligand, was purchased from InvivoGen (San Diego, CA, USA). MIP-1 $\alpha$, MIP-1 $\beta$, and RANTES antibodies were purchased from R\&D System (R\&D system Inc., Minneapolis, MN, USA). Mouse IgG was purchased from Sigma-Aldrich (St. Louis, MO, USA). Rabbit antibody against glyceraldehyde 3-phosphate dehydrogenase (GAPDH), anti-mouse IgG (horseradish peroxidase (HRP)-linked) antibody, and anti-rabbit IgG (HRPlinked) antibody were purchased from Cell Signaling Technology (Danvers, MA, USA). Mouse antibody against HIV-1 p24 was purchased from Abcam (Abcam, Cambridge, UK). All antibodies and reagents for flow cytometry assay were purchased from BD Bioscience (BD Bioscience, San Jose, CA, USA). Trichloroacetic acid (TCA) and acetone were purchased from Sigma-Aldrich.

\subsection{Preparation of Virus Stocks}

pHIV R3A-HSA was kindly provided by Dr. Lishan Su (Department of Microbiology and Immunology, The Lineberger Comprehensive Cancer Center, School of Medicine, The University of North Carolina). This is an HIV molecular clone with a highly pathogenic dual-tropic envelope (R3A) in the NL4-3 backbone [33], which was constructed by replacing the vpr gene with a mouse heat-stable antigen (HSA; CD24) [34]. The env defective HIV NL4-3 derivative pHIV NL4-3- $\triangle$ Env-eGFP (pNLENG1-ES-IRES-GFP) was described previously [35]. The HIV Bal.01 Env expression vector was obtained from the AIDS Research and Reference Reagent Program of the National Institute of Health. For single round HIV infection particle assembly, pHIV NL4-3- $\triangle$ Env-eGFP and pHIV Bal.01-Env were co-transfected into HEK-293 T cells with the transfection reagent PEIpro ${ }^{\circledR}$ (Polyplus transfection, New York, USA). For mouse CD24 reporter HIV particle assembly, pHIV R3A-HSA was transfected into HEK-293T cells with PEIpro ${ }^{\circledR}$. Virus-containing supernatant was collected at $48 \mathrm{~h}$ and $72 \mathrm{~h}$ post-transfection. The supernatant harvested from transfected HEK-293T cells was first filtered through a $0.45 \mu \mathrm{m}$ filter, and then purified and concentrated by centrifugation through a $10 \%$ sucrose solution $\left(8000 \mathrm{rpm}, 4{ }^{\circ} \mathrm{C}\right.$ for $\left.3 \mathrm{~h}\right)$.

\subsection{MTS Assay}

Cultured macrophages were incubated with or without imiquimod for $72 \mathrm{~h}$ in a humidified, 5\% $\mathrm{CO}_{2}$ atmosphere. Into each 96-well assay plate containing the cells in $100 \mu \mathrm{L}$ of culture medium, $20 \mu \mathrm{L}$ of MTS reagent (Promega Co., Madison, WI, USA) was added, then the plate was incubated in darkness at $37^{\circ} \mathrm{C}$ for $4 \mathrm{~h}$. The absorbance at $490 \mathrm{~nm}$ was recorded by a 96-well plate reader (SpectraMax M5, Molecular Devices, San Jose, CA, USA).

\subsection{Imiquimod Treatment and HIV Infection}

Monocyte-derived macrophages were treated with or without imiquimod under three different treatment conditions (before, simultaneously with, and after infection). The cells were infected with an equal amount of cell-free HIV strains (Bal (RT = $2 \times 10^{5}$ ), Jago $\left(\mathrm{RT}=7.5 \times 10^{4}\right)$, or YU2 $\left(\mathrm{RT}=1 \times 10^{5}\right)$ for $3 \mathrm{~h}$ at $37^{\circ} \mathrm{C}$. The cells were then washed three times with DMEM to remove input viruses and then RNAs and proteins were collected from the cells and the culture supernatant 9 days post-infection. 


\subsection{RNA Extraction and Real-Time Polymerase Chain Reaction}

Total RNAs from macrophages or cell-free supernatant were extracted using TRI Reagent or TRI Reagent BD (Sigma-Aldrich, St. Louis, MO, USA) according to the manufacturer's instructions. RNAs were subjected to a reverse transcription reaction by using the random primer, dNTPs, AMV reverse transcriptase, and RNasin ${ }^{\circledR}$ ribonuclease inhibitor (Promega Co., Madison, WI, USA) to obtain cDNA. cDNAs were then used as templates for the real-time polymerase chain reaction (real-time PCR) which was performed with PowerUp SYBR Green Master Mix (Applied Biosystems, Carlsbad, CA, USA). The level of GAPDH mRNA was used as an endogenous reference to normalize the quantities of target mRNAs. The oligonucleotide primers used in this study were synthesized by Integrated DNA Technologies, Inc. (Coralville, IA, USA) and listed in Table 1.

Table 1. Primer sets for real-time PCR.

\begin{tabular}{|c|c|c|c|c|}
\hline Primer & Accession No. & Orientation & Sequences & Product (bp) \\
\hline GAPDH & NM_002046 & $\begin{array}{l}\text { Sense } \\
\text { Antisense }\end{array}$ & $\begin{array}{l}\text { 5'-GGTGGTCTCCTCTGACTTCAACA-3' }^{\prime} \\
5^{\prime} \text {-GTTGCTGTAGCCAAATTCGTTGT-3 }\end{array}$ & 127 \\
\hline GAG & NC_001802.1 & $\begin{array}{l}\text { Sense } \\
\text { Antisense }\end{array}$ & $\begin{array}{l}\text { 5'-ATAATCCACCTATCCCAGTAGGAGAAA-3' } \\
5^{\prime} \text {-TTTGGTCCTTGTCTTATGTCCAGAATGC-3' }\end{array}$ & 115 \\
\hline CD4 & NM_001382706.1 & $\begin{array}{l}\text { Sense } \\
\text { Antisense }\end{array}$ & $\begin{array}{l}\text { 5'-AGTCCCTTTTAGGCACTTGC-3' } \\
\text { 5'-GATCATTCAGCTTGGATGG-3' }^{\prime}\end{array}$ & 224 \\
\hline CCR5 & NM_001100168.2 & $\begin{array}{l}\text { Sense } \\
\text { Antisense }\end{array}$ & 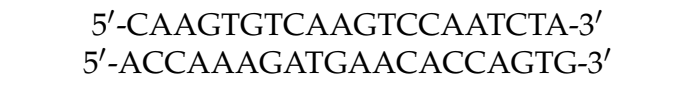 & 123 \\
\hline $\mathrm{MIP}-1 \alpha$ & NM_021006.5 & $\begin{array}{l}\text { Sense } \\
\text { Antisense }\end{array}$ & $\begin{array}{l}\text { 5'-GCTGACTACTTTGAGACGAGC-3' } \\
5^{\prime} \text {-CCAGTCCATAGAAGAGGTAGC-3' }\end{array}$ & 252 \\
\hline MIP-1 $\beta$ & NM_002984.4 & $\begin{array}{c}\text { Sense } \\
\text { Antisense }\end{array}$ & $\begin{array}{l}5^{\prime} \text { - CCAAACCAAAAGAAGCAAGC }-3^{\prime} \\
5^{\prime} \text { - AGAAACAGTGACAGTGGACC }-3^{\prime}\end{array}$ & 314 \\
\hline RANTES & NM_002985.3 & $\begin{array}{l}\text { Sense } \\
\text { Antisense }\end{array}$ & $\begin{array}{l}\text { 5'- CTGCATCTGCCTCCCCATA -3' } \\
5^{\prime} \text { - GCGGGCAATGTAGGCAAA -3' }\end{array}$ & 62 \\
\hline $\begin{array}{l}\text { HIV-1 LTR } \\
\text { RU/5 }\end{array}$ & NC_001802.1 & $\begin{array}{c}\text { Sense } \\
\text { Antisense }\end{array}$ & $\begin{array}{l}\text { 5'-TCTCTCTGGTTAGACCAGATCTG-3' } \\
5^{\prime} \text {-ACTGCTAGAGATTTTCCACACTG-3' }\end{array}$ & 180 \\
\hline IL-6 & NM_001371096 & $\begin{array}{c}\text { Sense } \\
\text { Antisense }\end{array}$ & $\begin{array}{c}\text { 5'-AGGAGACTTGCCTGGTGAAA-3' } \\
5^{\prime} \text {-CAGGGGTGGTTATTGCATCT-3' }\end{array}$ & 180 \\
\hline IL-8 & NM_000584 & $\begin{array}{l}\text { Sense } \\
\text { Antisense }\end{array}$ & $\begin{array}{l}\text { 5'-ATGACTTCCAAGCTGGCCGTGGCT-3' } \\
\text { 5'-TCTCAGCCCTCTTCAAAAACTTCTC-3' }\end{array}$ & 292 \\
\hline IL-1 $\beta$ & NM_000576 & $\begin{array}{c}\text { Sense } \\
\text { Antisense }\end{array}$ & $\begin{array}{l}\text { 5'-AGGTGCATCGTGCACATAAG-3' } \\
\text { 5'-AAGCTGATGGCCCTAAACAG-3' }\end{array}$ & 281 \\
\hline TNF- $\alpha$ & NM_000594 & $\begin{array}{l}\text { Sense } \\
\text { Antisense }\end{array}$ & $\begin{array}{c}\text { 5'-CGAGTGACAAGCCTGTAGC-3' } \\
\text { 5'-GGTGTGGGTGAGGAGCACAT-3' }\end{array}$ & 215 \\
\hline IL-10 & NM_001382624 & $\begin{array}{l}\text { Sense } \\
\text { Antisense }\end{array}$ & $\begin{array}{c}\text { 5'-CTTTAATAAGCTCCAAGAGAAAGGC-3' }^{\prime} \\
5^{\prime} \text {-CAGATCCGATTTTGGAGACC-3' }\end{array}$ & 167 \\
\hline IFN- $\alpha$ & NM_002169.3 & $\begin{array}{c}\text { Sense } \\
\text { Antisense }\end{array}$ & $\begin{array}{l}\text { 5'-TTTCTCCTGCCTGAAGAACAG-3' } \\
5^{\prime} \text {-GCTCATGATTTCTGCTCTGACA-3' }\end{array}$ & 373 \\
\hline IFN- $\beta$ & NM_002176.4 & $\begin{array}{c}\text { Sense } \\
\text { Antisense }\end{array}$ & $\begin{array}{c}\text { 5'-GCCGCATTGACCATCTATGAGA-3' } \\
\text { 5'-GAGATCTTCAGTTTCGGAGGTAAC-3' }\end{array}$ & 346 \\
\hline
\end{tabular}

\subsection{Western Blot}

Macrophages were lysed with RIPA buffer (Sigma-Aldrich, St. Louis, MO, USA) supplemented with a protease and phosphatase inhibitor cocktail $(100 \times$, Thermo Fisher Scientific, Waltham, MA, USA). Proteins from the culture supernatant were extracted by the TCA/acetone precipitation method. Briefly, $0.5 \mathrm{~mL}$ of culture supernatant was precipitated with $0.5 \mathrm{~mL}$ of $20 \% \mathrm{TCA}$ at $-20{ }^{\circ} \mathrm{C}$ for $1 \mathrm{~h}$ in an Eppendorf microcentrifuge tube. The 
mixture was centrifuged at $11,500 \mathrm{rpm}$ for $15 \mathrm{~min}$ at $4{ }^{\circ} \mathrm{C}$ and then the supernatant was discarded. The pellet was washed with $1 \mathrm{~mL}$ of ice-cold acetone three times and the pellet was left to dry at room temperature. The pellet was lysed with Western blot lysis buffer. The concentration of proteins was determined by BCA assay (Thermo Fisher Scientific, Waltham, MA, USA). Equal amounts of proteins, along with protein molecular weight, were separated on 4 to $12 \%$ Bis-Tris gels (Invitrogen, Grand Island, NY, USA) and transferred to an Immun-Blot ${ }^{\circledR}$ PVDF membrane (Bio-Rad, Hercules, CA, USA). The blots were blocked with $5 \%$ nonfat milk for $2 \mathrm{~h}$ at room temperature and then incubated with primary antibodies overnight at $4{ }^{\circ} \mathrm{C}$. The blots were washed in PBS with $0.1 \%$ Tween 20 (PBST) four times and then incubated with HRP-conjugated second antibodies for $2 \mathrm{~h}$ at room temperature. The blots were developed with SuperSignal West Pico Chemiluminescent Substrate (Thermo Fisher Scientific, Waltham, MA, USA) after 4 washes with PBST. The blots were then exposed to an iBright 1500 imaging analyzer (Invitrogen, Carlsbad, CA, USA).

\subsection{Detection of HIV Strong-Stop DNA}

To further study whether imiquimod could block HIV entry, we examined the effect of imiquimod on the expression of HIV strong-stop DNA which is the first product of HIV reverse transcription, an indicator of HIV entry [36,37]. HIV Bal was treated with RNase Free DNase I at room temperature for $30 \mathrm{~min}$ before the infection of the macrophages. Total DNA from cells and viral DNA products were collected at $3 \mathrm{~h}$ post-infection with the QIAamp DNA Mini kit (Qiagen, Inc., Valencia, CA, USA). Strong-stop DNA was then quantified by the real-time PCR with HIV LTR RU/5 primers (Table 1).

\subsection{Flow Cytometry}

Macrophages were treated with imiquimod for $24 \mathrm{~h}$ prior to HIV R3A-HSA infection, infected macrophages were harvested at $72 \mathrm{~h}$ post-infection with Versene solution $(0.48 \mathrm{mM}$ EDTA). The cells were immediately washed with a cell staining buffer prior to staining with APC-anti-mouse CD24 (M1/69), and APC-isotype IgG antibody-stained cells were used as the negative control. Macrophages were treated with or without imiquimod for $24 \mathrm{~h}$ before being harvested with the Versene solution. The harvested cells were stained with PE mouse anti-human CD4 antibody and PE mouse anti-human CCR5 antibody. PE-isotype IgG antibody-stained cells were used as the negative control. The stained cells were measured by a FACSCanto II (BD Bioscience, San Jose, CA, USA) and analyzed using FlowJo software (Tree Star Inc., Ashland, OR, USA).

\subsection{Measurement of Green Fluorescence}

Macrophages were treated with or without imiquimod for $24 \mathrm{~h}$ prior to HIV NL4-3$\triangle$ Env-eGFP-Bal infection. Three days after infection, the cells were washed with $1 \times$ PBS and stained for nuclei with Hochest 33342 (Invitrogen, Carlsbad, CA, USA) for $15 \mathrm{~min}$. The stained cells were then photographed under a confocal microscope (Nikon, A1R, Tokyo, Japan) for green fluorescence measurement.

\subsection{ELISA}

Cell-free culture supernatant was collected from macrophage cultures treated with or without imiquimod for $24 \mathrm{~h}$. The CC chemokines (MIP- $1 \alpha$, MIP-1 $\beta$, and RANTES), tumor necrosis factor-alpha (TNF- $\alpha$ ), interleukin (IL)-6, IL-8, IL-1 $\beta$, and IL-10 were measured with ELISA kits based on the manufacturer's instructions (R\&D Systems Inc., Minneapolis, MN, USA).

\subsection{Data Statistical Analysis}

Data were expressed as means \pm standard deviations (SD) from at least three independent experiments. For comparison of the mean of two groups (treated versus untreated), statistical significance was measured by the Student's $t$-test. If there were more than two groups, a one-way analysis of variance followed by the Newman-Keul's test were used. All 
statistical analysis was performed using GraphPad Prism 5.0 Software (GraphPad Software Inc., San Diego, CA). Statistical significance was defined as $p<0.05, p<0.01$.

\section{Results}

\subsection{Imiquimod Inhibits HIV Infection of Macrophages}

To determine the effect of TLR7 activation by imiquimod on HIV infection in macrophages, cells were treated with or without imiquimod for $24 \mathrm{~h}$ prior to infection with different HIV strains (Bal, YU2, and Jago). On day 9 post-infection, we measured the mRNA expression of the HIV Gag gene and protein level of HIV p24 to evaluate the anti-viral effect of imiquimod. As shown in Figure 1, the imiquimod treatment of macrophages dose-dependently inhibited the HIV Gag gene expression in both cells (intracellular) and culture supernatant (extracellular). In addition, imiquimod significantly inhibited HIV p24 protein expression in macrophages and this inhibition was dose-dependent (Figure 2A). Morphologically, HIV Bal-infected macrophages showed characteristic giant syncytium formation (Figure 2B). However, imiquimod-treated macrophages failed to develop HIVinduced giant syncytia (Figure 2B).

A
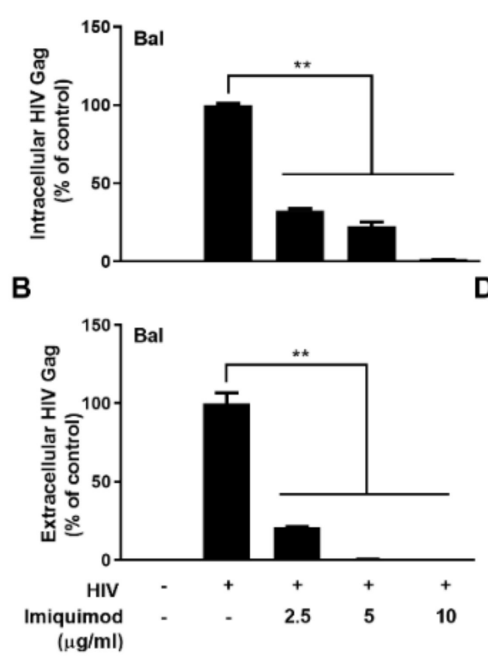
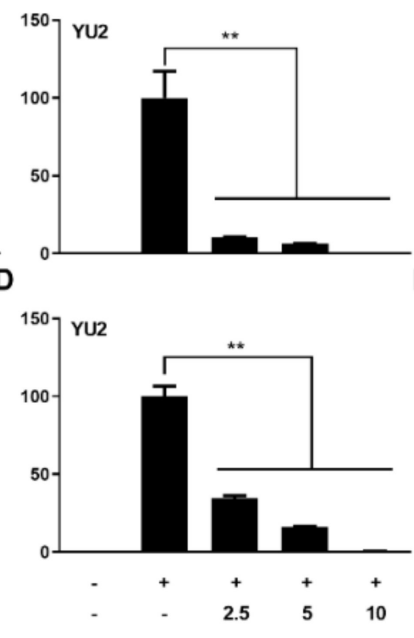

HIV Gag expression

E
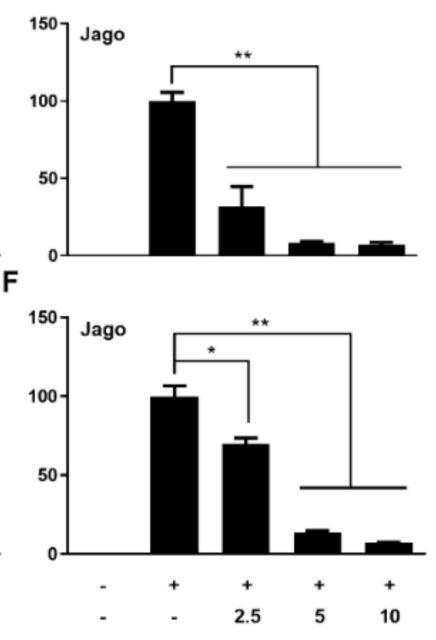

Figure 1. Imiquimod inhibits HIV Gag gene expression. (A-F) Macrophages were treated with or without imiquimod at indicated concentrations for $24 \mathrm{~h}$ prior to HIV (Bal, YU2, and Jago) infection. Cellular and culture supernatant RNAs were collected on day 9 post-infection and subjected to the real-time PCR for HIV Gag gene expression. Data are shown as mean $\pm \mathrm{SD}$ of 3 independent experiments $\left({ }^{*} p<0.05,{ }^{* *} p<0.01\right)$.

To visualize the effect of imiquimod on HIV, we performed the infection experiments with HIV R3A-HSA and HIV NL4-3- $\Delta$ Env-eGFP-Bal. Macrophages were treated with or without imiquimod for $24 \mathrm{~h}$ prior to infection with the viruses. We measured the expression of mouse CD24 and GFP in the infected macrophages treated with or without imiquimod on day 3 post-infection. As shown in Figure 3A, imiquimod treatment of macrophages dose-dependently downregulated mouse CD24 expression. In addition, imiquimod-treated macrophages expressed significantly fewer GFP-positive cells in comparison with the untreated cells (Figure 3B).

To determine whether the inhibitory effect of imiquimod on HIV is not associated with cytotoxicity, we treated macrophages with different concentrations of imiquimod for $72 \mathrm{~h}$ and measured cell viability by MTS assay. As shown in Figure S1, imiquimod had little cytotoxic effect on macrophages at a dose as high as $160 \mu \mathrm{g} / \mathrm{mL}$. 


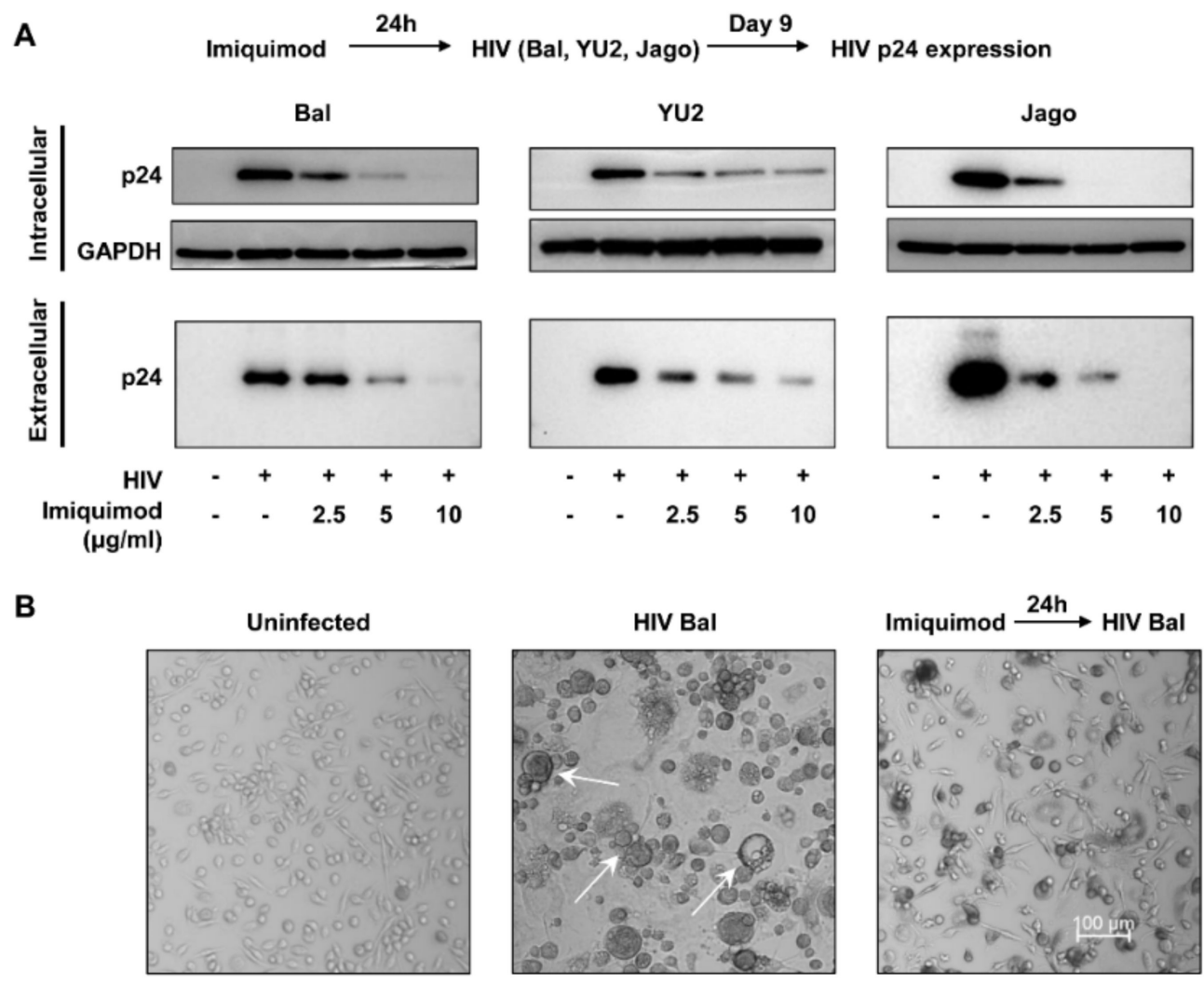

Figure 2. Imiquimod inhibits HIV p24 expression. (A) Macrophages were treated with or without imiquimod at indicated concentrations for $24 \mathrm{~h}$ prior to infection with different HIV strains (Bal, YU2, and Jago). Cellular and culture supernatant proteins were collected on day 9 post-infection and subjected to the Western blot assay for HIV p24 expression. (B) The morphology of uninfected macrophages comparing with HIV Bal-infected cells pretreated with or without imiquimod $(10 \mu \mathrm{g} / \mathrm{mL})$ was photographed by a confocal microscope (Nikon, A1R, Tokyo, Japan) on day 9 post-infection. The arrows indicate HIV-induced giant syncytium formation in macrophages.

\subsection{Imiquimod Blocks HIV Entry into Macrophages}

To further determine imiquimod-mediated HIV inhibition, we also examined the antiHIV effect of imiquimod under three different treatment conditions (before, simultaneously with, and after infection). Briefly, macrophages were treated with imiquimod for $24 \mathrm{~h}$ prior to HIV Bal infection (before), or cells were treated with imiquimod and infected with HIV Bal simultaneously (simul), or cells were first infected with HIV Bal for $3 \mathrm{~h}$ and then treated with imiquimod (after). Similarly, the mRNA expression of the HIV Gag gene and the protein expression of viral p24 were measured on day 9 post-infection. As shown in Figure 4, while imiquimod significantly inhibited the HIV Gag gene (Figure 4A,B) and p24 protein expression (Figure 4C,D) under all of the treatment conditions, the treatment of the cells with imiquimod before infection was the most effective in suppressing HIV. These similar findings were also observed in the HIV NL4-3- $\Delta$ Env-eGFP-Bal infection experiments under the same imiquimod treatment conditions. As shown in Figure 4E, cells pretreated with imiquimod had the lowest level of GFP-positive cells, while treatment after infection had little impact on the GFP expression in the cells.

\subsection{Imiquimod Induces CC Chemokines}

Based on the findings in the HIV infection experiments, we next studied the cellular factors associated with HIV entry into macrophages. It is well known that CC chemokines (MIP-1 $\alpha$, MIP-1 $\beta$, and RANTES) are the natural ligands for the HIV co-receptor CCR5 and could block HIV entry [38]. We thus examined whether imiquimod can induce CC 
chemokines production in macrophages, and we found that the imiquimod treatment of macrophages dose-dependently induced the expression of all three CC chemokines at both mRNA and protein levels (Figure 5A,B). In addition, we found that imiquimod could block the expression of the strong-stop DNA in macrophages (Figure $5 \mathrm{C}$ ), the first product of HIV reverse transcription [36,37]. The expression level of HIV strong-stop DNA from the imiquimod treated group was downregulated by $\sim 1.5$ folds to $\sim 4$ folds compared to the untreated group (Figure 5C). To determine the role of the CC chemokines (MIP- $1 \alpha$, MIP-1 $\beta$, and RANTES) in imiquimod-mediated HIV inhibition, we used the neutralization antibodies to MIP- $1 \alpha$, MIP-1 $\beta$, and RANTES in the blocking experiments. We observed that the neutralization antibodies to MIP- $1 \alpha$, MIP- $1 \beta$, and RANTES could compromise the effect of imiquimod on the inhibition of HIV in macrophages (Figure 5D).

A

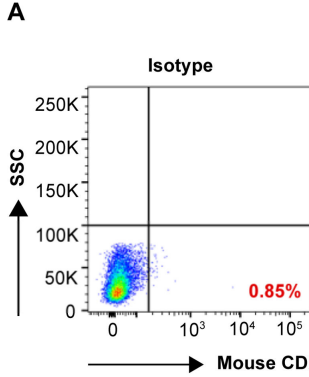

B

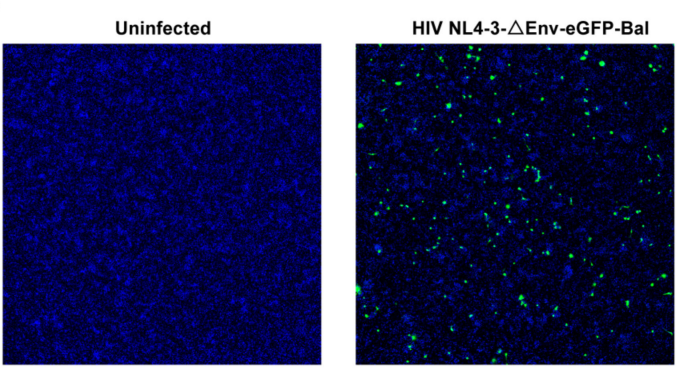

Imiquimod $(\mu \mathrm{g} / \mathrm{ml}) \stackrel{24 \mathrm{~h}}{\longrightarrow}$ HIV R3A-HSA $\stackrel{\text { Day3 }}{\longrightarrow}$ Mouse CD24

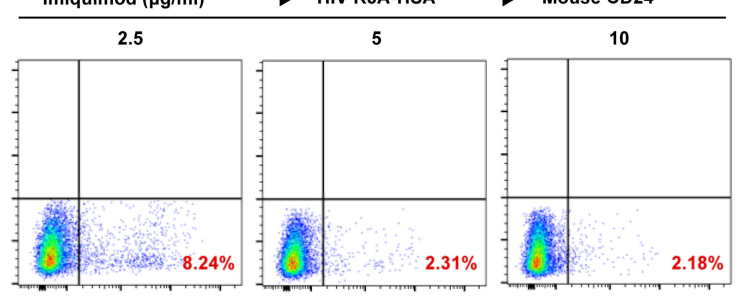

Imiquimod $(\mu \mathrm{g} / \mathrm{m})$

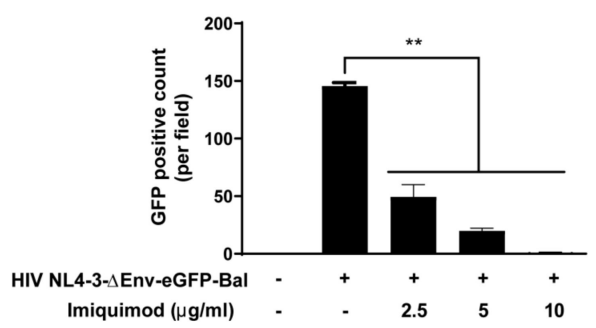

Imiquimod $(\mu \mathrm{g} / \mathrm{ml}) \stackrel{24 \mathrm{~h}}{\longrightarrow}$ HIV NL4-3- $\triangle$ Env-eGFP-Bal $\stackrel{\text { Day3 }}{\longrightarrow}$ GFP

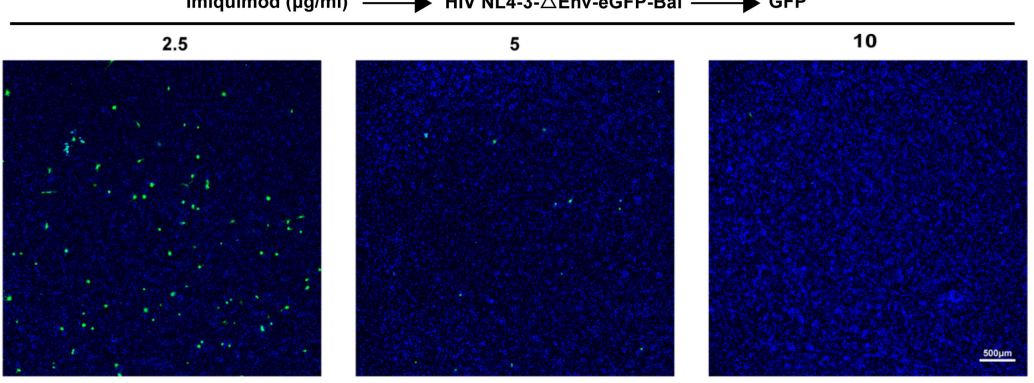

Figure 3. Imiquimod inhibits HIV R3A-HSA and HIV NL4-3- $\Delta$ Env-eGFP-Bal infection. Macrophages were treated with or without imiquimod at the indicated concentrations for $24 \mathrm{~h}$ prior to infection. (A) Cells were washed 3 times to remove unattached HIV R3A-HSA viruses with DMEM at $4 \mathrm{~h}$ post-infection and then harvested cells at $72 \mathrm{~h}$ post-infection. The cells were then subjected to flow cytometry for mouse CD24 expression. (B) Cells were washed to remove unattached HIV NL4-3$\triangle$ Env-eGFP-Bal viruses with DMEM at $24 \mathrm{~h}$ post-infection. The green fluorescence protein expression was measured by confocal microscope (Nikon, A1R, Tokyo, Japan) at $72 \mathrm{~h}$ post-infection. Scale bar, $500 \mu \mathrm{m}\left({ }^{* *} p<0.01\right)$.

\subsection{Imiquimod Induces Inflammatory Cytokines}

Because TLR7 activation could activate the nuclear factor kappa-B (NF-kB) signaling pathway $[39,40]$, we investigated the effect of imiquimod on inflammatory cytokine expression in macrophages. We observed that although imiquimod had little effect on total NF- $\mathrm{kB}$ p65, it induced the phosphorylated NF-kB p65 expression in a dose-dependent manner 
(Figure 6A). As a result, there was a significant increase in the mRNA expression of inflammatory cytokines (IL-6, IL-8, IL-1 $\beta$, and TNF- $\alpha$ ) and anti-inflammatory cytokine (IL-10) in imiquimod-treated macrophages (Figure $6 \mathrm{~B}, \mathrm{C}$ ). In addition, we also measured the protein levels in the supernatant of macrophage cultures. As shown in Figure $6 \mathrm{~B}, \mathrm{D}$, imiquimodtreated macrophages produced significantly higher levels of IL-10, IL-6, IL-8, IL-1 $\beta$, and TNF- $\alpha$ in comparison with untreated cells, and this upregulation was dose-dependent.

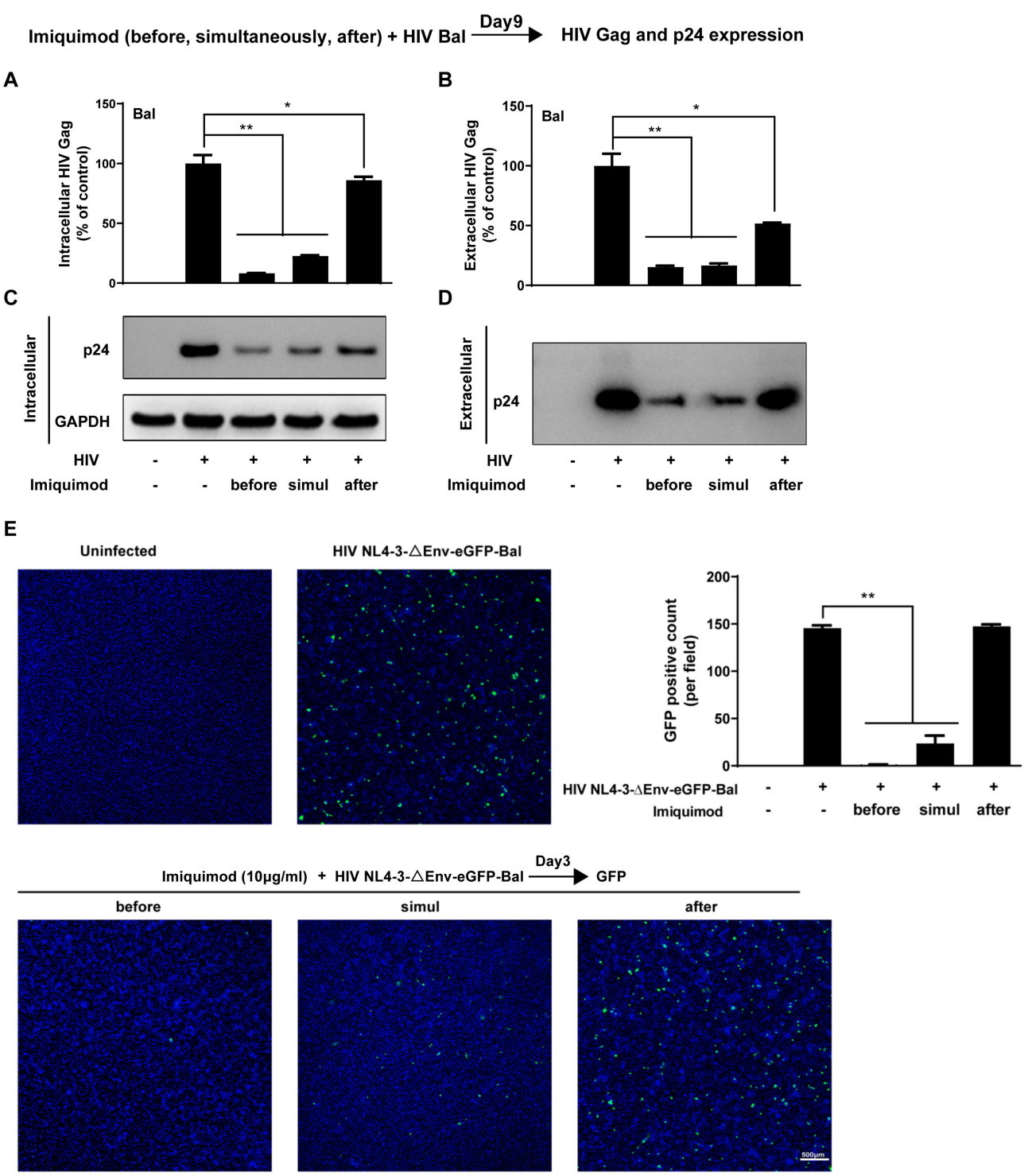

Figure 4. Imiquimod blocks HIV entry into macrophages. (A-D) Macrophages were treated with either imiquimod $(10 \mu \mathrm{g} / \mathrm{mL}$ ) for $24 \mathrm{~h}$ prior to HIV Bal infection (before), or imiquimod and infected with HIV Bal simultaneously (simul), or infected with HIV Bal for $3 \mathrm{~h}$ prior to imiquimod treatment (after). Cellular and culture supernatant RNAs were collected on day 9 post-infection and subjected to the real-time PCR for HIV Gag gene expression $(\mathbf{A}, \mathbf{B})$. Proteins of cells and culture supernatant were collected on day 9 post-infection and subjected to Western blot for HIV p24 expression (C,D). (E) Macrophages were treated with either imiquimod $(10 \mu \mathrm{g} / \mathrm{mL})$ for $24 \mathrm{~h}$ prior to HIV NL-4-3$\Delta$ Env-eGFP-Bal infection (before), or imiquimod and infected with HIV NL-4-3- $\Delta$ Env-eGFP-Bal simultaneously (simul), or infected with HIV NL-4-3- $\Delta$ Env-eGFP-Bal for $24 \mathrm{~h}$ prior to imiquimod treatment (after). At $72 \mathrm{~h}$ post-infection, the green fluorescence was measured by confocal microscope. Data are shown as mean $\pm \mathrm{SD}$ of 3 independent experiments. Scale bar, $500 \mu \mathrm{m}\left({ }^{*} p<0.05,{ }^{* *} p<0.01\right)$. 
A

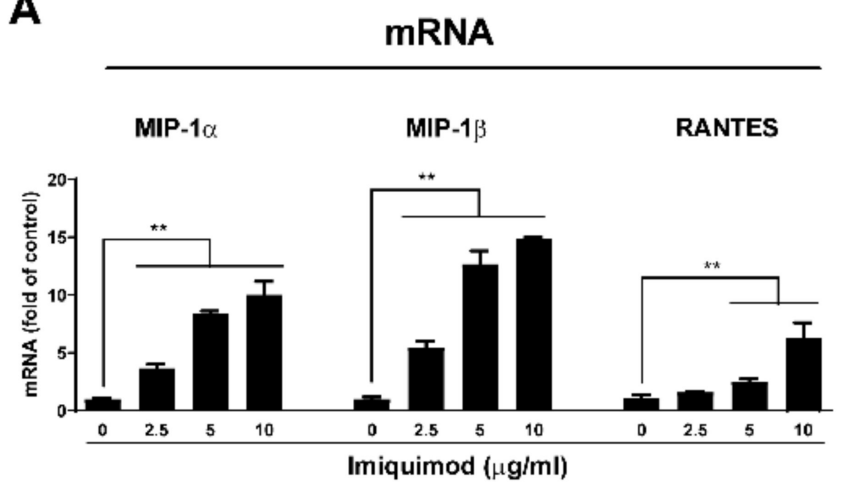

C

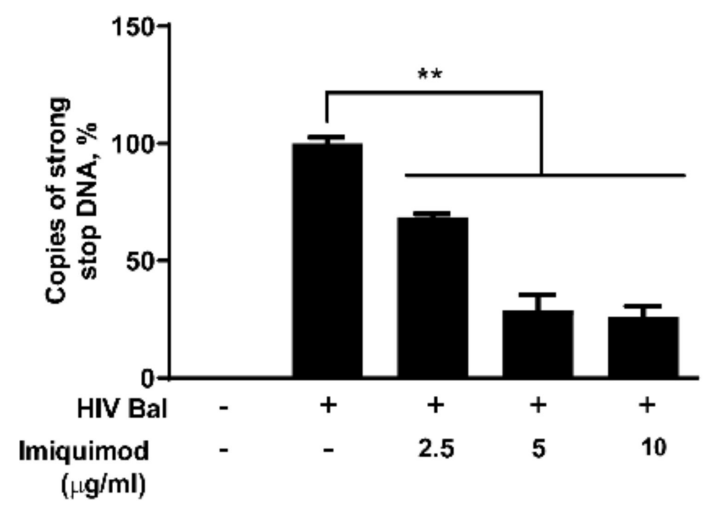

B

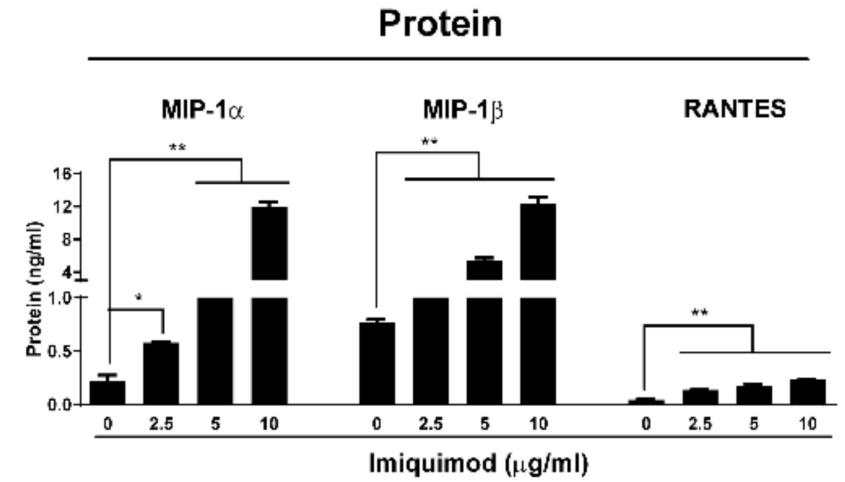

D

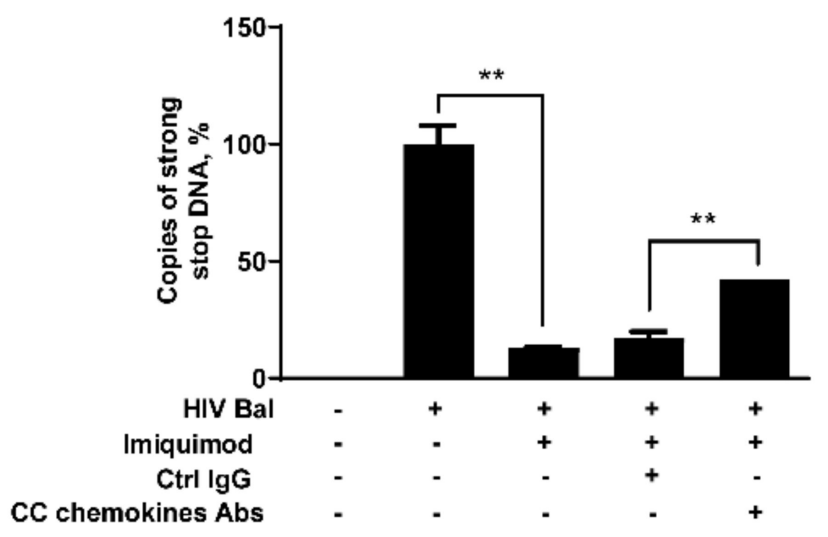

Figure 5. Imiquimod induces CC chemokines. (A,B) Macrophages were treated with or without imiquimod at the indicated concentrations. Total cellular RNA was extracted at $6 \mathrm{~h}$ post-treatment and subjected to the real-time PCR for the mRNA levels of MIP- $1 \alpha$, MIP-1 $\beta$, RANTES, and GAPDH (A). Twenty-four hours after imiquimod treatment, culture supernatant was then collected and subjected to the ELISA assay for the protein levels of MIP-1 $\alpha$, MIP-1 $\beta$, and RANTES (B). (C) HIV strong-stop DNA was detected in macrophages pretreated with imiquimod at the indicated concentrations. (D) Macrophages were pretreated with imiquimod $(10 \mu \mathrm{g} / \mathrm{mL})$ for $24 \mathrm{~h}$ and then were incubated with $20 \mu \mathrm{g} / \mathrm{mL}$ control IgG or a mixture of neutralization antibodies to MIP- $1 \alpha$, MIP- $1 \beta$, and RANTES for $2 \mathrm{~h}$ prior to infection with HIV Bal which had been treated with RNase Free DNase I. HIV strong-stop DNA was quantified at $3 \mathrm{~h}$ post-infection. Data are shown as mean \pm SD of three independent experiments $\left({ }^{*} p<0.05,{ }^{* *} p<0.01\right)$.

\subsection{Imiquimod Suppresses CD4 and CCR5 Expression}

HIV (R5-tropic strain) infection of macrophages requires two key entry receptors (CD4 and CCR5) on the cell surfaces. Therefore, we studied whether imiquimod has an impact on the expression of these receptors. As shown in Figure 7, imiquimod treatment of macrophages inhibited the expression of HIV entry receptors CD4/CCR5 at both mRNA (1.5 to 3.5 folds decrease) and protein (1.8 to 2.2 folds decrease) levels. 
A

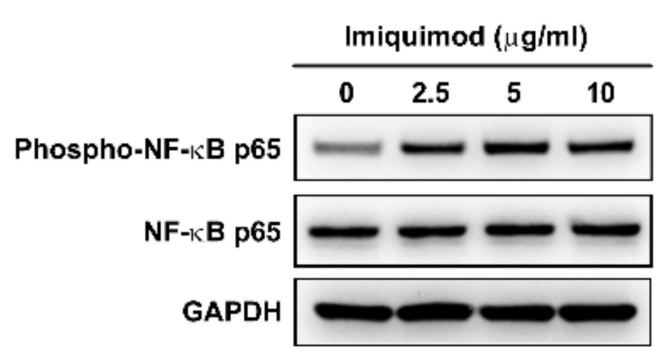

C

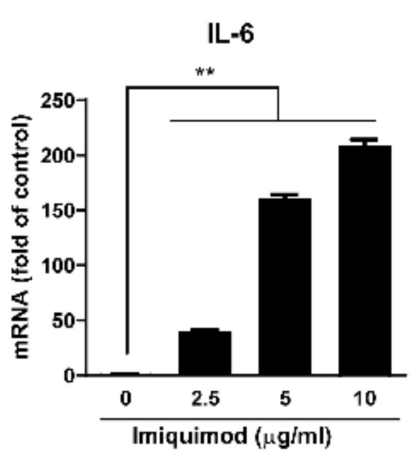

D

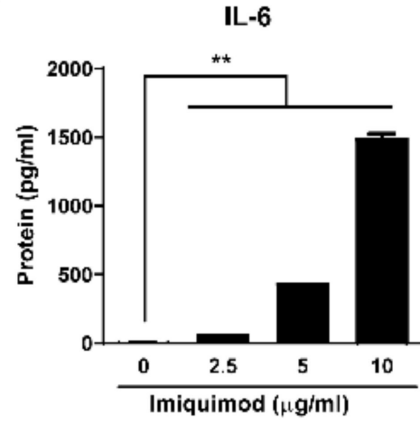

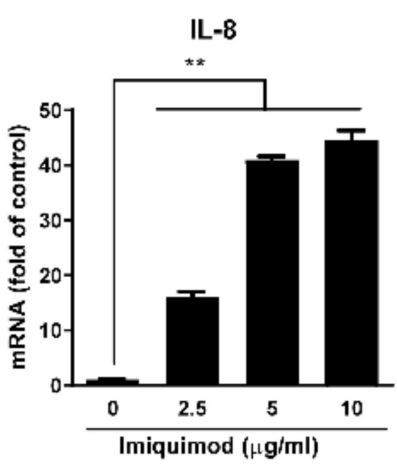

IL-8

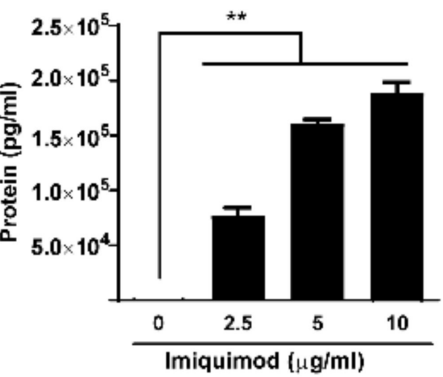

B

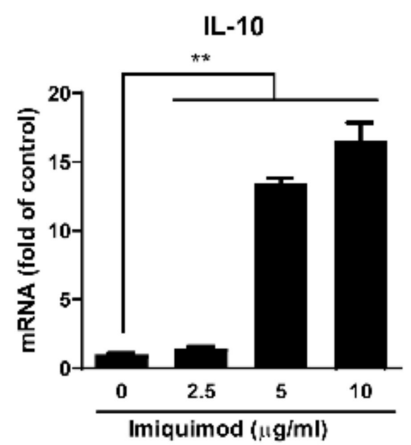

IL-1 $\beta$

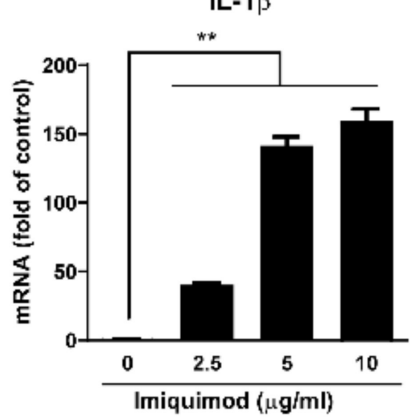

IL-1 $\beta$

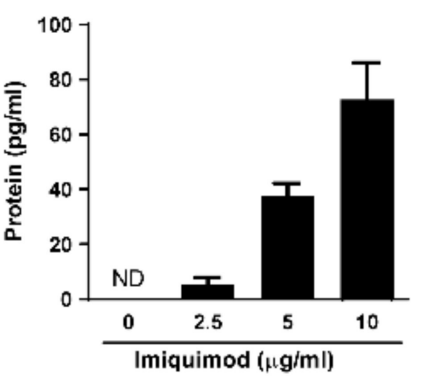

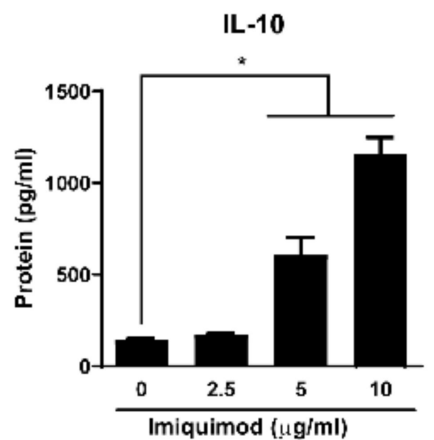

TNF- $\alpha$

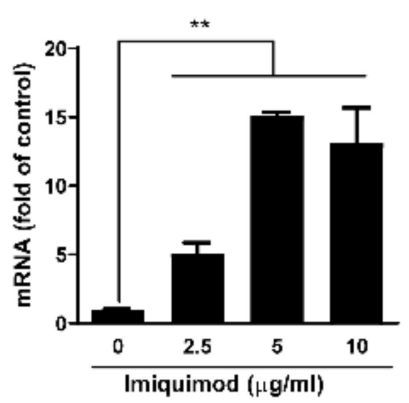

TNF $=\alpha$

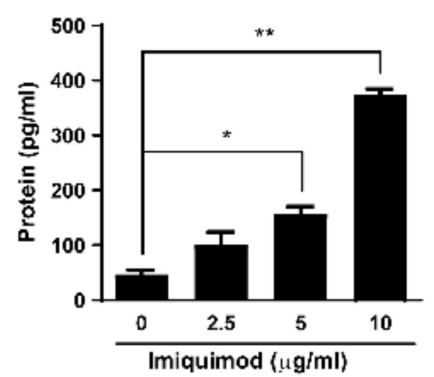

Figure 6. Effect of imiquimod on NF- $\mathrm{KB}$ signaling pathway. (A) Macrophages were treated with imiquimod at indicated concentrations for $24 \mathrm{~h}$. Then cellular protein was collected and subjected to Western blot for GAPDH, NF-kB p65, and Phospho-NF-KB p65 expression. (B) Macrophages were treated with imiquimod at indicated doses for $6 \mathrm{~h}$ or $24 \mathrm{~h}$, and then cellular RNA or culture supernatant was collected and subjected to real-time PCR or ELISA for IL-10 expression. (C) Macrophages were treated with imiquimod at indicated concentrations for $6 \mathrm{~h}$. Then cellular RNA was collected and subjected to real-time PCR for IL-6, IL-8, IL-1 $\beta$, and TNF- $\alpha$ expression. (D) Macrophages were treated with imiquimod at indicated concentrations for $24 \mathrm{~h}$. Then culture supernatant was collected and subjected to ELISA for IL-6, IL-8, IL-1 $\beta$, and TNF- $\alpha$ expression. Data are shown as mean \pm SD of three independent experiments (ND: not detected, ${ }^{*} p<0.05$, $* * p<0.01)$. 
A

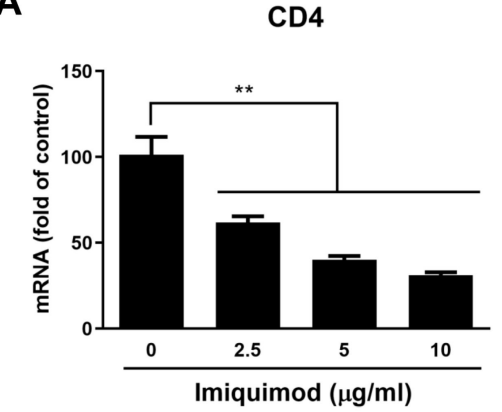

C

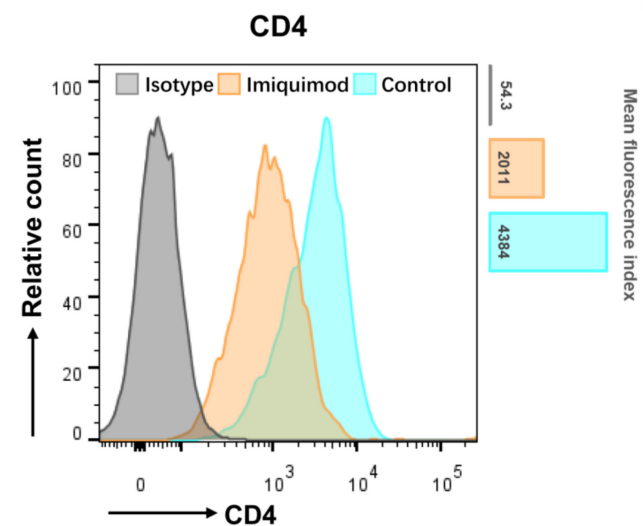

B

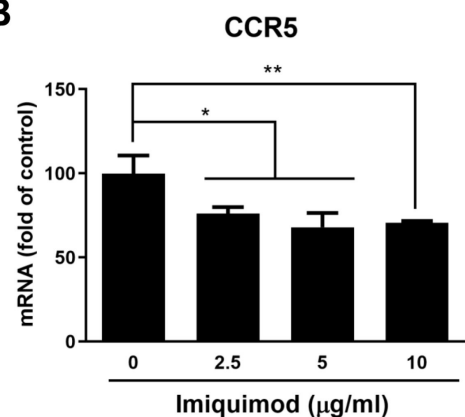

D

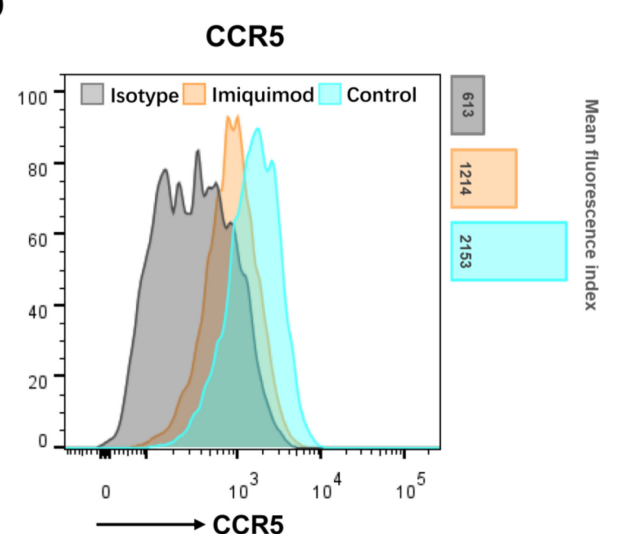

Figure 7. Effect of imiquimod on CD4 and CCR5. (A,B) Macrophages were treated with imiquimod at the indicated concentrations for $12 \mathrm{~h}$. Cellular RNAs were collected and subjected to real-time PCR for CD4 and CCR5 mRNA expression. (C,D) Macrophages were treated with imiquimod $(10 \mu \mathrm{g} / \mathrm{mL})$ for $24 \mathrm{~h}$ and then collected for the flow cytometry analysis of CD4 and CCR5 protein expression. Data are shown in $\mathrm{A}$ and $\mathrm{B}$ as mean $\pm \mathrm{SD}$ of three independent experiments $\left({ }^{*} p<0.05,{ }^{* *} p<0.01\right)$. Flow cytometry data shown in $\mathrm{C}$ and $\mathrm{D}$ are the representative pictures of two independent experiments.

\section{Discussion}

TLR7 is highly expressed by plasmacytoid dendritic cells [41] and other immune cells including macrophages [42]. Agonists to TLR7 are attractive therapeutic agents with the potential of activating innate and acquired immunity against viral infections, including HIV [43-45]. In the present study, we demonstrated that TLR7 activation by imiquimod could effectively inhibit the infection of primary macrophages by different strains of HIV (Figures 1-3). The anti-HIV properties associated with TLR7 activation have been documented by several groups using distinct small-molecule TLR7/8 agonists. Bam et al. [13] reported that the TLR7 agonist GS-9620 could potently inhibit the acute HIV infection of the human peripheral blood mononuclear cells (PBMC). However, they observed that GS-9620 had little effect on HIV in purified CD4 $4^{+} \mathrm{T}$ cells and macrophages. In contrast, Buitendijk et al., showed that in addition to HIV inhibition in activated PBMC, gardiquimod, another TLR7 agonist, could inhibit the HIV infection of macrophages when the cells were treated prior to or shortly after infection [12]. These conflicting findings could be due to the use of different TLR7 ligands and cell types in these studies. It should be noted that we used primary human macrophages derived from purified monocytes which were cultured in the absence of any growth factors such as granulocyte-macrophage colony-stimulating factor (GM-CSF). GM-CSF has been shown to have a contradictory role in the modulation of HIV infection [46].

To determine the mechanism(s) involved in imiquimod's action on HIV infection of macrophages, we first examined the effect of imiquimod on the cytokines (IL-6, IL-8, IL-1 $\beta$, IL-10, and TNF- $\alpha$ ), including IFNs. We found that imiquimod could induce the phosphorylation of NF- $\mathrm{BB}$ p65 and the production of inflammatory cytokines (Figure 6), 
which agrees with the studies by others $[16,39,40,47-50]$. Several inflammatory cytokines are known to modulate HIV infection/replication in vitro, with their effects being either stimulatory (TNF- $\alpha$, IL-1 $\beta$, IL-6, and IL-8) or inhibitory (IFN- $\alpha$ and IL-10). As a potent anti-inflammatory cytokine, IL-10 can counteract the adverse effects of pro-inflammatory cytokines on HIV infection and inhibit HIV replication [51]. Therefore, it is likely that imiquimod-induced IL-10 compromises the stimulatory effects of the pro-inflammatory cytokines (TNF- $\alpha$, IL-1 $\beta$, IL-6, and IL-8) on HIV infection/replication in macrophages. In addition to the cytokines described above, we also examined the impact of imiquimod on the expression of the antiviral cytokine IFNs. Several studies demonstrated that the TLR7 agonists (GS-9620, gardiquimod, and resiquimod) could inhibit HIV replication in vitro [11-13] by inducing IFNs. The studies concluded that the induction of IFN- $\alpha$ is largely responsible for the TLR7 agonist-mediated anti-HIV effect. Interestingly, we observed that imiquimod did not significantly induce the expression of type I IFNs in macrophages (Figure S2). These conflicting findings could be due to differences in cell types and culture conditions. In this study, we used primary human macrophages derived from purified monocytes cultured in the absence of the growth factor, GM-CSF.

We hypothesized that imiquimod blocked HIV infection at the viral entry level based on the following observations: 1 . Imiquimod treatment of macrophages before infection was the most effective in HIV inhibition (Figure 4); 2. Imiquimod significantly inhibited the expression of HIV strong-stop DNA (Figure 5C), the first synthetic (minus) strand DNA from viral RNA; 3 . Imiquimod induced TNF- $\alpha$ which is known to target the HIV entry step specifically in macrophages [52]. TNF- $\alpha$ inhibits the entry of HIV into macrophages through downregulating CD4 and CCR5 receptors on the cell surface [53,54]. In addition, TNF- $\alpha$ can induce the expression of CC chemokines (MIP- $1 \alpha$, MIP-1 $\beta$, and RANTES) [55,56], the ligands for CCR5. Therefore, we examined the impact of imiquimod on the HIV entry cellular factor (CD4, CCR5, and CC chemokines) and we found that imiquimod treatment of macrophages induced expression of the CC chemokines (MIP- $1 \alpha$, MIP-1 $\beta$, and RANTES) at both mRNA and protein levels (Figure 5A,B). Imiquimod also inhibited the expression of CD4 and CCR5 receptors (Figure 7). Importantly, the role of CC chemokines in imiquimodmediated HIV inhibition was confirmed by the finding that the addition of antibodies to the CC chemokines in the macrophage cultures largely blocked the effect of imiquimod on HIV inhibition (Figure 5D).

In summary, our study, for the first time, provides compelling experimental evidence that TLR7 activation by imiquimod significantly suppresses HIV infection through regulating the viral entry cellular factors in macrophages. Imiquimod treatment of macrophages could activate the NF- $\mathrm{kB}$ signaling pathway and induce multiple pro-inflammatory (TNF- $\alpha$, IL-1 $\beta$, IL-6, and IL-8) and anti-inflammatory (IL-10) cytokines. Importantly, imiquimod could induce the production of the CC chemokines which can competitively bind to CCR5 and block HIV entry into macrophages. In addition, imiquimod downregulates the expression of CD4 and CCR5 (Figure 8). While the precise cellular and molecular mechanisms for imiquimod-mediated HIV inhibition remain to be determined, the induction of CC chemokines and the downregulation of CD4 and CCR5 should be largely responsible for much of the imiquimod-mediated anti-HIV activity in macrophages. These findings are clinically important as they indicate that activating the intracellular antiviral immunity by imiquimod has the potential for HIV treatment. However, future ex vivo and in vivo investigations with animal models and clinical specimens are necessary, not only for confirming our in vitro findings, but also for developing a TLR7 agonist-based therapy for HIV disease. 


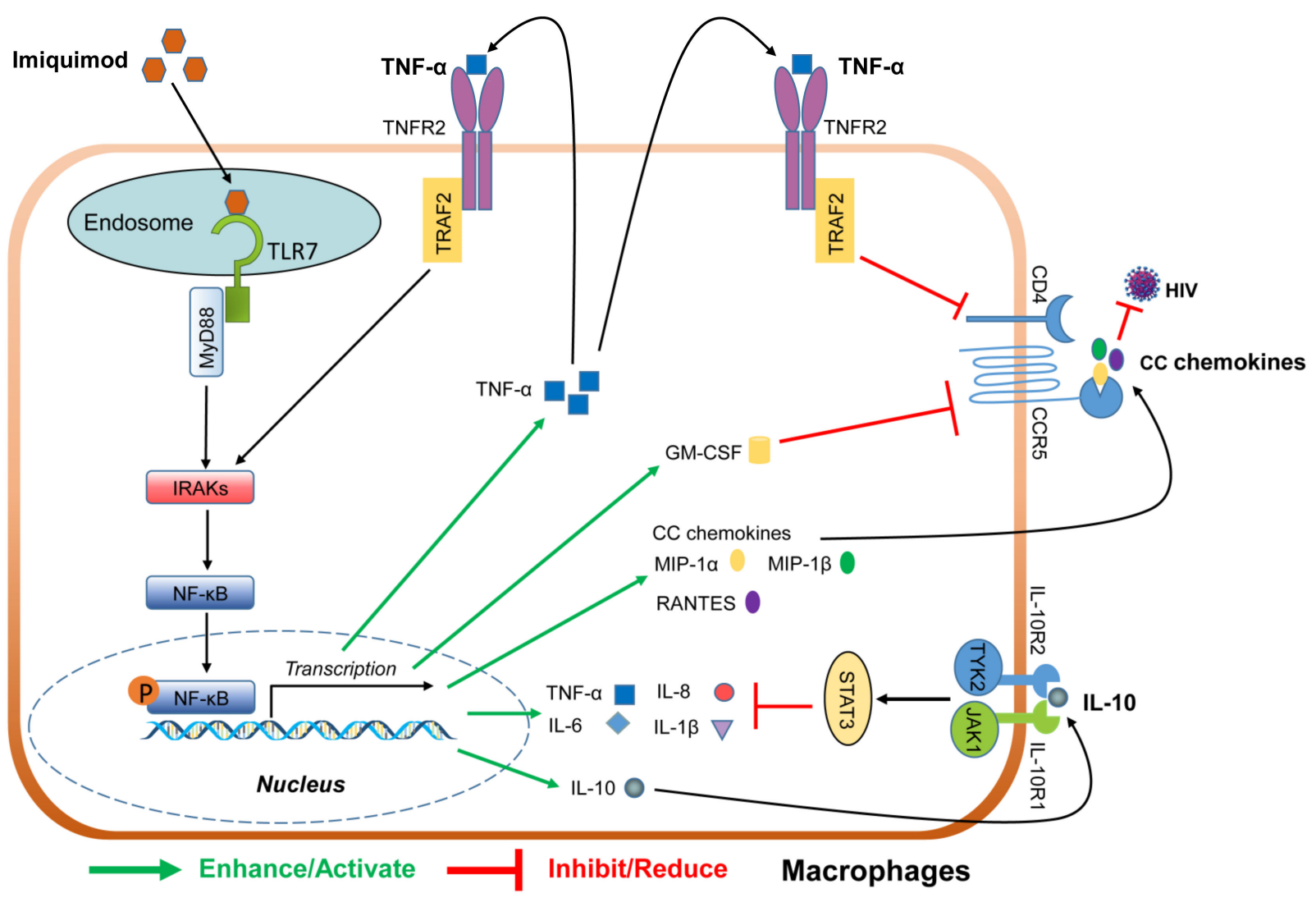

Figure 8. Schematic diagram of mechanisms for imiquimod-mediated HIV inhibition in macrophages. Through the activation of the NF-KB signaling pathway by binding to TLR7, imiquimod induces CC chemokines (MIP- $1 \alpha$, MIP- $1 \beta$, and RANTES), TNF- $\alpha$, IL-6, IL-1 $\beta$, IL-8, and IL-10. As the natural ligands for HIV entry co-receptor CCR5, the CC chemokines can inhibit HIV entry into macrophages. Through binding to TNF receptor 2 (TNFR2), TNF- $\alpha$ inhibits the CD4 and CCR5 expression. In addition, TNF- $\alpha$ can induce the CC chemokines through binding to TNFR2 and activating the NF- $\mathrm{KB}$ signaling pathway. These combined activities result in the blocking of HIV entry into macrophages by imiquimod. As a potent anti-inflammatory cytokine, IL-10 can counteract the adverse effect of the pro-inflammatory cytokines on HIV infection and inhibit HIV replication. Therefore, it is likely that imiquimod-induced IL-10 compromises the stimulatory effects of the pro-inflammatory cytokines (TNF- $\alpha$, IL-6, IL-1 $\beta$, and IL-8) on HIV infection/replication in macrophages.

Supplementary Materials: The following are available online at https:/ /www.mdpi.com/article/10 .3390 / biology10070661/s1, Figure S1: Effect of Imiquimod on cell viability of macrophages, Figure S2: Effect of Imiquimod on IFNs expression, File S1: Original images of blots.

Author Contributions: Conceptualization, F.-Z.M., X.W., W.-H.H., W.H. and W.-Z.H.; methodology, F.-Z.M., J.-B.L., X.W., P.W. and W.-H.H.; software, F.-Z.M. and J.-B.L.; validation, F.-Z.M., J.-B.L. and P.W.; formal analysis, F.-Z.M. and J.-B.L.; investigation, F.-Z.M.; resources, W.-Z.H.; data curation, F.-Z.M.; writing—original draft preparation, F.-Z.M., W.-H.H., W.H. and W.-Z.H.; writing-review and editing, F.-Z.M., W.H. and W.-Z.H.; visualization, F.-Z.M.; supervision, W.H. and W.-Z.H.; project administration, X.W., W.H. and W.-Z.H.; funding acquisition, W.-Z.H. All authors have read and agreed to the published version of the manuscript.

Funding: This research received no external funding.

Institutional Review Board Statement: Not applicable.

Informed Consent Statement: Not applicable.

Data Availability Statement: Not applicable.

Conflicts of Interest: The authors declare no conflict of interest. 


\section{References}

1. Carty, M.; Guy, C.; Bowie, A.G. Detection of Viral Infections by Innate Immunity. Biochem. Pharmacol. 2021, 183, 114316. [CrossRef] [PubMed]

2. Clayton, K.L.; Garcia, J.V.; Clements, J.E.; Walker, B.D. HIV Infection of Macrophages: Implications for Pathogenesis and Cure. Pathog. Immun. 2017, 2, 179-192. [CrossRef] [PubMed]

3. Kruize, Z.; Kootstra, N.A. The Role of Macrophages in HIV-1 Persistence and Pathogenesis. Front. Microbiol. 2019, 10, 2828. [CrossRef] [PubMed]

4. Koenig, S.; Gendelman, H.E.; Orenstein, J.M.; Canto, M.C.D.; Pezeshkpour, G.H.; Yungbluth, M.; Janotta, F.; Aksamit, A.; Martin, M.A.; Fauci, A.S. Detection of AIDS virus in macrophages in brain tissue from AIDS patients with encephalopathy. Science 1986, 233, 1089-1093. [CrossRef]

5. Bachmann, N.; The Swiss HIV Cohort Study; von Siebenthal, C.; Vongrad, V.; Turk, T.; Neumann, K.; Beerenwinkel, N.; Bogojeska, J.; Fellay, J.; Roth, V.; et al. Determinants of HIV-1 reservoir size and long-term dynamics during suppressive ART. Nat. Commun. 2019, 10, 3193. [CrossRef]

6. Wong, M.E.; Jaworowski, A.; Hearps, A.C. The HIV Reservoir in Monocytes and Macrophages. Front. Immunol. 2019, 10, 1435. [CrossRef]

7. Nguyen, T.A.; Pang, K.C.; Masters, S.L. Intercellular communication for innate immunity. Mol. Immunol. 2017, 86, 16-22. [CrossRef]

8. Kawai, T.; Akira, S. Toll-like Receptors and Their Crosstalk with Other Innate Receptors in Infection and Immunity. Immunity 2011, 34, 637-650. [CrossRef] [PubMed]

9. Asami, J.; Shimizu, T. Structural and functional understanding of the toll-like receptors. Protein Sci. 2021, 30, 761-772. [CrossRef]

10. Blasius, A.L.; Beutler, B. Intracellular Toll-like Receptors. Immunity 2010, 32, 305-315. [CrossRef]

11. Hofmann, H.; Vanwalscappel, B.; Bloch, N.; Landau, N.R. TLR7/8 agonist induces a post-entry SAMHD1-independent block to HIV-1 infection of monocytes. Retrovirology 2016, 13, 83. [CrossRef]

12. Buitendijk, M.; Eszterhas, S.K.; Howell, A.L. Gardiquimod: A Toll-Like Receptor-7 Agonist That Inhibits HIV Type 1 Infection of Human Macrophages and Activated T cells. AIDS Res. Hum. Retrovir. 2013, 29, 907-918. [CrossRef]

13. Bam, R.A.; Hansen, D.; Irrinki, A.; Mulato, A.; Jones, G.S.; Hesselgesser, J.; Frey, C.R.; Cihlar, T.; Yant, S.R. TLR7 Agonist GS-9620 Is a Potent Inhibitor of Acute HIV-1 Infection in Human Peripheral Blood Mononuclear Cells. Antimicrob. Agents Chemother. 2017, 61. [CrossRef]

14. Lee, J.; Chuang, T.-H.; Redecke, V.; She, L.; Pitha, P.M.; Carson, D.A.; Raz, E.; Cottam, H.B. Molecular basis for the immunostimulatory activity of guanine nucleoside analogs: Activation of Toll-like receptor 7. Proc. Natl. Acad. Sci. USA 2003, 100, 6646-6651. [CrossRef] [PubMed]

15. Harrison, C.J.; Jenski, L.; Voychehovski, T.; Bernstein, D. Modification of immunological responses and clinical disease during topical R-837 treatment of genital HSV-2 infection. Antivir. Res. 1988, 10, 209-223. [CrossRef]

16. Megyeri, K.; Au, W.C.; Rosztoczy, I.; Raj, N.B.; Miller, R.L.; Tomai, M.A.; Pitha, P.M. Stimulation of interferon and cytokine gene expression by imiquimod and stimulation by Sendai virus utilize similar signal transduction pathways. Mol. Cell. Biol. 1995, 15, 2207-2218. [CrossRef] [PubMed]

17. Hengge, U.R.; Cusini, M. Topical immunomodulators for the treatment of external genital warts, cutaneous warts and molluscum contagiosum. Br. J. Dermatol. 2003, 149 (Suppl. 66), 15-19. [CrossRef] [PubMed]

18. To, E.E.; Erlich, J.; Liong, F.; Luong, R.; Liong, S.; Bozinovski, S.; Seow, H.; O’Leary, J.J.; Brooks, D.A.; Vlahos, R.; et al. Intranasal and epicutaneous administration of Toll-like receptor 7 (TLR7) agonists provides protection against influenza A virus-induced morbidity in mice. Sci. Rep. 2019, 9, 2366. [CrossRef] [PubMed]

19. Angelopoulou, A.; Alexandris, N.; Konstantinou, E.; Mesiakaris, K.; Zanidis, C.; Farsalinos, K.; Poulas, K. Imiquimod-A toll like receptor 7 agonist-Is an ideal option for management of COVID 19. Environ. Res. 2020, 188, 109858. [CrossRef]

20. Saiag, P.; Bauhofer, A.; Bouscarat, F.; Aquilina, C.; Ortonne, J.P.; Dupin, N.; Mougin, C. Imiquimod 5\% cream for external genital or perianal warts in human immunodeficiency virus-positive patients treated with highly active antiretroviral therapy: An open-label, noncomparative study. Br. J. Dermatol. 2009, 161, 904-909. [CrossRef]

21. Sanclemente, G.; Herrera, S.; Tyring, S.; Rady, P.; Zuleta-Tobón, J.J.; Correa, L.-A.; He, Q.; Wolff, J.-C. Human papillomavirus (HPV) viral load and HPV type in the clinical outcome of HIV-positive patients treated with imiquimod for anogenital warts and anal intraepithelial neoplasia. J. Eur. Acad. Dermatol. Venereol. 2007, 21, 1054-1060. [CrossRef] [PubMed]

22. Kreuter, A.; Potthoff, A.; Brockmeyer, N.H.; Gambichler, T.; Stücker, M.; Altmeyer, P.; Swoboda, J.; Pfister, H.; Wieland, U. Imiquimod Leads to a Decrease of Human Papillomavirus DNA and to a Sustained Clearance of Anal Intraepithelial Neoplasia in HIV-Infected Men. J. Investig. Dermatol. 2008, 128, 2078-2083. [CrossRef]

23. Conant, M.A. Immunomodulatory therapy in the management of viral infections in patients with HIV infection. J. Am. Acad. Dermatol. 2000, 43, S27-S30. [CrossRef] [PubMed]

24. Akhtar, L.; Qin, H.; Muldowney, M.T.; Yanagisawa, L.L.; Kutsch, O.; Clements, J.E.; Benveniste, E.N. Suppressor of Cytokine Signaling 3 Inhibits Antiviral IFN- $\beta$ Signaling To Enhance HIV-1 Replication in Macrophages. J. Immunol. 2010, 185, 2393-2404. [CrossRef] [PubMed]

25. Foster, T.L.; Wilson, H.D.; Iyer, S.S.; Coss, K.; Doores, K.; Smith, S.; Kellam, P.; Finzi, A.; Borrow, P.; Hahn, B.; et al. Resistance of Transmitted Founder HIV-1 to IFITM-Mediated Restriction. Cell Host Microbe 2016, 20, 429-442. [CrossRef] 
26. Harman, A.N.; Lai, J.; Turville, S.; Samarajiwa, S.; Gray, L.; Marsden, V.; Mercier, S.K.; Jones, K.; Nasr, N.; Rustagi, A.; et al. HIV infection of dendritic cells subverts the IFN induction pathway via IRF-1 and inhibits type 1 IFN production. Blood 2011, 118, 298-308. [CrossRef] [PubMed]

27. Okumura, A.; Alce, T.; Lubyova, B.; Ezelle, H.; Strebel, K.; Pitha, P.M. HIV-1 accessory proteins VPR and Vif modulate antiviral response by targeting IRF-3 for degradation. Virology 2008, 373, 85-97. [CrossRef]

28. Doehle, B.P.; Hladik, F.; McNevin, J.P.; McElrath, M.J.; Gale, M. Human Immunodeficiency Virus Type 1 Mediates Global Disruption of Innate Antiviral Signaling and Immune Defenses within Infected Cells. J. Virol. 2009, 83, 10395-10405. [CrossRef]

29. Liu, H.; Zhou, R.; Liu, Y.; Guo, L.; Wang, X.; Hu, W.; Ho, W. HIV infection suppresses TLR3 activation-mediated antiviral immunity in microglia and macrophages. Immunology 2020, 160, 269-279. [CrossRef]

30. Zhou, Y.; Wang, X.; Liu, M.-Q.; Hu, Q.; Song, L.; Ye, L.; Zhou, D.; Ho, W. A critical function of toll-like receptor-3 in the induction of anti-human immunodeficiency virus activities in macrophages. Immunology 2010, 131, 40-49. [CrossRef]

31. Li, J.; Wang, Y.; Wang, X.; Ye, L.; Zhou, Y.; Persidsky, Y.; Ho, W. Immune activation of human brain microvascular endothelial cells inhibits HIV replication in macrophages. Blood 2013, 121, 2934-2942. [CrossRef]

32. Berger, E.A.; Doms, R.W.; Fenyö, E.-M.; Korber, B.; Littman, D.R.; Moore, J.P.; Sattentau, Q.J.; Schuitemaker, H.; Sodroski, J.; Weiss, R.A. A new classification for HIV-1. Nature 1998, 391, 240. [CrossRef] [PubMed]

33. Zhang, L.; Jiang, Q.; Li, G.; Jeffrey, J.; Kovalev, G.; Su, L. Efficient infection, activation, and impairment of pDCs in the BM and peripheral lymphoid organs during early HIV-1 infection in humanized rag2 $-/-\gamma \mathrm{C}-/-$ mice in vivo. Blood 2011, 117, 6184-6192. [CrossRef] [PubMed]

34. Jamieson, B.D.; Zack, J.A. In Vivo Pathogenesis of a Human Immunodeficiency Virus Type 1 Reporter Virus. J. Virol. 1998, 72, 6520-6526. [CrossRef] [PubMed]

35. Levy, D.N.; Aldrovandi, G.M.; Kutsch, O.; Shaw, G.M. Dynamics of HIV-1 recombination in its natural targeT cells. Proc. Natl. Acad. Sci. USA 2004, 101, 4204-4209. [CrossRef] [PubMed]

36. Song, M.; Balakrishnan, M.; Gorelick, R.J.; Bambara, R.A. A Succession of Mechanisms Stimulate Efficient Reconstituted HIV-1 Minus Strand Strong Stop DNA Transfer. Biochemistry 2009, 48, 1810-1819. [CrossRef]

37. Basu, V.P.; Song, M.; Gao, L.; Rigby, S.T.; Hanson, M.N.; Bambara, R.A. Strand transfer events during HIV-1 reverse transcription. Virus Res. 2008, 134, 19-38. [CrossRef]

38. Kalinkovich, A.; Weisman, Z.; Bentwich, Z. Chemokines and chemokine receptors: Role in HIV infection. Immunol. Lett. 1999, 68, 281-287. [CrossRef]

39. Hemmi, H.; Kaisho, T.; Takeuchi, O.; Sato, S.; Sanjo, H.; Hoshino, K.; Horiuchi, T.; Tomizawa, H.; Takeda, K.; Akira, S. Small anti-viral compounds activate immune cells via the TLR7 MyD88-dependent signaling pathway. Nat. Immunol. 2002, 3, 196-200. [CrossRef]

40. Haas, F.; Yamauchi, K.; Murat, M.; Bernasconi, M.; Yamanaka, N.; Speck, R.; Nadal, D. Activation of NF- B via Endosomal Toll-Like Receptor 7 (TLR7) or TLR9 Suppresses Murine Herpesvirus 68 Reactivation. J. Virol. 2014, 88, 10002-10012. [CrossRef]

41. Petes, C.; Odoardi, N.; Gee, K. The Toll for Trafficking: Toll-Like Receptor 7 Delivery to the Endosome. Front. Immunol. 2017, 8 , 1075. [CrossRef]

42. Cros, J.; Cagnard, N.; Woollard, K.; Patey, N.; Zhang, S.-Y.; Senechal, B.; Puel, A.; Biswas, S.K.; Moshous, D.; Picard, C.; et al. Human CD14dim Monocytes Patrol and Sense Nucleic Acids and Viruses via TLR7 and TLR8 Receptors. Immunity 2010, 33, 375-386. [CrossRef]

43. Patinote, C.; Karroum, N.B.; Moarbess, G.; Cirnat, N.; Kassab, I.; Bonnet, P.-A.; Deleuze-Masquéfa, C. Agonist and antagonist ligands of toll-like receptors 7 and 8: Ingenious tools for therapeutic purposes. Eur. J. Med. Chem. 2020, 193, 112238. [CrossRef] [PubMed]

44. Takahama, S.; Yamamoto, T. Pattern Recognition Receptor Ligands as an Emerging Therapeutic Agent for Latent HIV-1 Infection. Front. Cell. Infect. Microbiol. 2020, 10, 216. [CrossRef] [PubMed]

45. Huang, X.; Zhang, X.; Lu, M. Recent trends in the development of Toll-like receptor 7/8-targeting therapeutics. Expert Opin. Drug Discov. 2021, 1-12. [CrossRef]

46. Kedzierska, K.; Rainbird, M.A.; Lopez, A.F.; Crowe, S.M. Effect of GM-CSF on HIV-1 replication in monocytes/macrophages in vivo and in vitro: A review. Veter. Immunol. Immunopathol. 1998, 63, 111-121. [CrossRef]

47. Weeks, C.E.; Gibson, S.J. Induction of Interferon and Other Cytokines by Imiquimod and Its Hydroxylated Metabolite R-842 in Human Blood Cells In Vitro. J. Interf. Res. 1994, 14, 81-85. [CrossRef] [PubMed]

48. Gibson, S.J.; Imbertson, L.M.; Wagner, T.L.; Testerman, T.; Reiter, M.J.; Miller, R.L.; Tomai, M.A. Cellular Requirements for Cytokine Production in Response to the Immunomodulators Imiquimod and S-27609. J. Interf. Cytokine Res. 1995, 15, 537-545. [CrossRef] [PubMed]

49. Wagner, T.L.; Horton, V.L.; Carlson, G.L.; Myhre, P.E.; Gibson, S.J.; Imbertson, L.M.; Tomai, M.A. Induction of cytokines in cynomolgus monkeys by the immune response modifiers, imiquimod, S-27609 and S-28463. Cytokine 1997, 9, 837-845. [CrossRef]

50. Testerman, T.L.; Gerster, J.F.; Imbertson, L.M.; Reiter, M.J.; Miller, R.L.; Gibson, S.J.; Wagner, T.L.; Tomai, M.A. Cytokine induction by the immunomodulators imiquimod and S-27609. J. Leukoc. Biol. 1995, 58, 365-372. [CrossRef]

51. Singh, H.; Samani, D.; Nain, S.; Dhole, T.N. Interleukin-10 polymorphisms and susceptibility to ARV associated hepatotoxicity. Microb. Pathog. 2019, 133, 103544. [CrossRef] [PubMed] 
52. Herbein, G.; Montaner, L.J.; Gordon, S. Tumor necrosis factor alpha inhibits entry of human immunodeficiency virus type 1 into primary human macrophages: A selective role for the 75-kilodalton receptor. J. Virol. 1996, 70, 7388-7397. [CrossRef] [PubMed]

53. Herbein, G.; Doyle, A.G.; Montaner, L.J.; Gordon, S. Lipopolysaccharide (LPS) down-regulates CD4 expression in primary human macrophages through induction of endogenous tumour necrosis factor (TNF) and IL-1ß. Clin. Exp. Immunol. 1995, 102, 430-437. [CrossRef] [PubMed]

54. Di Marzio, P.; Tse, J.; Landau, N.R. Chemokine Receptor Regulation and HIV Type 1 Tropism in Monocyte-Macrophages. AIDS Res. Hum. Retroviruses 1998, 14, 129-138. [CrossRef]

55. Lane, B.R.; Markovitz, D.M.; Woodford, N.L.; Rochford, R.; Strieter, R.M.; Coffey, M.J. TNF-alpha inhibits HIV-1 replication in peripheral blood monocytes and alveolar macrophages by inducing the production of RANTES and decreasing $\mathrm{C}-\mathrm{C}$ chemokine receptor 5 (CCR5) expression. J. Immunol. 1999, 163, 3653-3661.

56. McManus, C.M.; Brosnan, C.F.; Berman, J.W. Cytokine induction of MIP-1 alpha and MIP-1 beta in human fetal microglia. J. Immunol. 1998, 160, 1449-1455. [PubMed] 